\title{
OPINION
}

\section{Europe Kidnapped}

\section{Spanish Voices on Citizenship and Exile*}

\author{
Massimo La Torre
}

Having to deal with exile and citizenship, and Europe, two Spanish voices, María Zambrano's and Max Aub's, may be brought into play as a reference for a fruitful debate. I believe they both have a lot to say to us on these two issues that are once again central in the European political debate. They both wrote about Europe taken hostage by totalitarian forces at the end of 1930s: El rapto de Europa (Europe Kidnapped) is a theatre piece by Aub composed in 1945, where he dramatized the attempts of a brave group of resistants led by Varian Fry to help people to escape from Marseille to America. And in the 1940s María Zambrano wrote a booklet La agonía de Europa (Europe's Agony) that is also a response to the rhetoric of a united Europe then spread over by National Socialists whose suggestive echo we find in two pamphlets composed by a Swedish legal theorist, Karl Olivecrona, England eller Tyskland (England or Germany), 1940, and Amerika och Europa (America and Europe), 1942.

Both La agonía de Europa by Zambrano and El rapto de Europa by Aub have little, if anything, to do with a book titled El rapto de Europa once more, published in 1954 by Luís Díez del Corral. Corral, like Zambrano a student of José Ortega y Gasset, was a faithful disciple, at least as far as the analysis of Europe's decadence is concerned, the European continent being considered by Corral as 'kidnapped' by nonEuropean powers, somehow and ante litteram by globalization, which will profit, to distinct ends, of European technical achievements and their grandiose instrumental rationality, furthermore a Europe 'kidnapped' by rebellious masses that intend to replace rights with needs. María Zambrano's booklet on the contrary is a somewhat critical response to La rebelión de las masas (The Revolt of the Masses) by Ortega y Gasset. The latter is quite an ambiguous book, published at the end of the 1920s, where democratic participation seems to be an intractable problem for a civilized society, and the solution of the European crisis is seen in a European federation with somewhat illiberal traits, an anticipation perhaps of what Hermann Heller had ironically labelled as 'authoritarian liberalism ${ }^{1}$ - actually a form

* Previous versions of this paper given at the Conference on 'Belonging and Displacement: European Mobility Labyrinths and Spanish Mirrors. In Light of History' (European Studies Centre, St. Anthony College, Oxford, 21-22 May, 2018), and at the Conference 'People on The Move: Migrants, Refugees, and Citizenship Rights' (University of Tallinn, 7-8 February, 2019). To Mario Ruiz Sanz in memory.

1 See Hermann Heller, 'Autoritärer Liberalismus?,' Die Neue Rundschau 44 (1933): 289-98. 
of illiberal liberalism, liberalism without democracy, that was later to be considered as in principle practicable and perhaps even desirable by Friedrich Hayek. ${ }^{2}$

It seems that Europe's existential condition is marked, even plagued, by the experience of exile. ${ }^{3}$ And exile is the opposed extreme to being and living as a citizen. At least it has been so in the so-called short century, the twentieth, and it is again so, in these two first decades of the second millennium. The twentieth, 'short' century beginning with the First World War, saw as an outcome of that internecine conflict a first massive movement of forced migrations: Anatolian Greeks expelled from a country they had been living in since Homer's times, Armenians deported into the desert to starve there, Russians to flee from both White and Red armies. In the interwar time there was a strong migratory movement from Eastern Europe to Western European states, France especially. Simenon's first novels are full of Baltic and Polish emigrants: Pëtr le Letton (Peter the Latvian), actually, is the first Maigret story. In a later story, Maigret et son mort (Maigret's Dead Man), the killers are a savage gang of Eastern European seasonal workers. Irène Némirowski's fine novels, written in the 1920s and 1930s, are obsessively dealing with the destiny of Russian and Ukrainian refugees, their striving for integration and against estrangement, and the more or less failed search of a new home.

That huge, eruptive flux of people is well thematized in the novel that perhaps best interprets migrants' odyssey, fears and sufferance, Das Totenschiff (The Death Ship), published at end of the 1920s, and written by B. Traven, actually Ret Marut, himself an exile, a refugee, being one of the leaders of the Bavarian council revolution of 1919. Joseph Roth's first novel Hotel Savoy is again a story about a refugee coming from Russia, a Heimatlose, a stateless young man, through whom you find represented what many at the time considered the scum of the earth, twenty years before Arthur Koestler's memoirs having that disparaging expression as its title. Friedrich Glauser tells stories about working class people wandering around Europe to earn a miserable living. Nina Berberova's literary miniatures, for instance Chroniques de Billancourt (Billancourt Tales), or Vladislav Khodasevich's, her husband's, great novel, Necropolis, are the expression of a despair and a nostalgia that can only be fed by the memory of the lost mother Russia.

And then we had Fascism and the Nazi dictatorship literally producing millions of people without a home and a passport. Klaus Mann, one of Thomas Mann's sons, is one of them and writes about them, beginning in 1934 with Flucht in den Norden, whose English title is Journey into Freedom. Erich Maria Remarque develops

2 See Friedrich August Hayek, 'The Economic Condition of Interstate Federalism', in idem, Individualism and Economic Order (Chicago: University of Chicago Press, 1948).

3 So that, from this angle, the Bible itself might be read as a book telling stories of runaway people (cf. Johann Hinrich Claussen, Das Buch der Flucht. Die Bibel in 40 Stationen (Munich: Beck, 2018). 
an epic of the German stateless, writing novels so moving and influential such as Arc de Triomphe or Eine Nacht in Lissabon (The Night in Lisbon). Stefan Zweig's book on the lost world of pre-totalitarian Europe, Die Welt von Gestern (The World of Yesterday), is a refugee's work, and could only have been written from the exile's perspective. The lost world is the one rooted in citizenship and Heimat, two things that to the Austrian writer now seem somewhat utopian. Ödön von Horvath's plays and novels can only be understood and appreciated from the vantage point of the exile and the wanderer. Not to speak of the great trilogy by Lion Feuchtwanger, dealing with the end of the Weimar republic, whose third and final volume is significantly entitled Exil (Exile) - indeed a novel about the German refugees in France and their via crucis.

We are on the move, this we read in Transit, the novel by Anna Seghers elaborating on her escape from occupied France. Ein Gast auf dieser Erde, such is the subtitle of Tarabas, one late novel by Joseph Roth, speaking once again of an exile. And the protagonist of Roth's last novel, published in 1939 in the Netherlands, the visionary Die Legende vom heiligen Trinker (The Legend of the Holy Drinker), is once more a migrant; he's a desperate, poor, permanently drunken Polish tramp, wandering in the Parisian streets in search of a few coins, living a life that is not too far away from the existence depicted by George Orwell in his Down and Out in Paris and London (1933). That was a time when one seemed to lose one home after the other, when the experience of fatherland crumbling down and imposed exile impending anew was once and again rehearsed in Europe, this so hundred, thousand times kidnapped continent. Joseph Roth saw and said it: 'One loses one home after the other, I say to myself. Here I am, sitting ready to take the road' ('Man verliert eine Heimat nach der anderen, sage ich mir. Hier sitze ich am Wanderstab'). ${ }^{4}$

After World War II the forced migrations will not stop; just the contrary, they will recommence and go on in full swing. We shall have a general exodus from Eastern Europe, entire populations transported, deported better, from one region to another: Germans expelled, Poles expelled and relocated where another people used to live; Breslau becoming Wroclaw, Stettin Szczecin, Königsberg Kaliningrad. Later, in 1956, we had a Hungarian refugees wage, people well received in Austria and other Western European countries. And then the pieds noirs fleeing Algeria, etcetera, etcetera.

Now, one important part of this migratory tragedy was played in the Iberian Peninsula after 1939. In that year, as is well known, General Franco won the Spanish civil war. About a million people were forced to leave the country not to be slaughtered or sent to concentration camps. Entire villages and districts of the Spanish regions were in movement, especially towards France, and a more fortu- 
nate few towards Mexico and other Latin American countries. An entire culture, the civic Republican Spanish intelligentsia, was forced to flee. Liberalism, socialism, anarchism, were violently uprooted from the Iberian Peninsula to be replaced by National Catholicism and Fascism. Between 1936 and 1939, when the Franco troops occupied a village or a town, the first people to be executed were los maestros, the teachers of public schools, then free-masons, and anarchists. There was a holocaust of Biblical dimensions directed against that part of the Spanish population that was suspect of upholding Enlightenment values. The fatherland's original values were expelled from its own territory: 'Se alejaron del suelo patrio' - Max Aub's words - 'la mayoria de sus autenticos valores.'

So, exile was a common experience for an entire generation of Spanish intellectuals. It was their destiny and their final destination. Many of them did not survive to see Franco dying and democracy being restored in Spain. Among these there were Arturo Barea and Max Aub. Barea, the author of La forja de un rebelde (The Forging of a Rebel), a great literary tapestry about Second Republic and civil war Spain, favourably reviewed by George Orwell, ended his days in England in 1957. Max Aub died in Mexico in 1972, three years before the Spanish dictator's definitive agony.

Aub had been already quite well known before the civil war, a young novelist and poet developing his views on literature in the company of artists like Federico García Lorca or León Felipe and Luis Buñuel. García Lorca was massacred in Granada, León Felipe, Luis Buñuel, together with Max Aub and several others, landed in Mexico. But Max Aub's journey was not an easy one. He had to go through the odyssey of escape to France, deportation to Northern Africa, and then again a tight escape to Mexico. He was not spared the experience and despair of concentration camps.

Exile became the central theme of Max Aub's literary production, and the loadstar of his existential self-reflection. This has been once stressed by Francisco Ayala, a friend of his and a companion in the Mexican exile, and it is true. Practically, there is no piece or story by Aub in which exile is not dealt with explicitly or implicitly looming behind the lines. El rapto de Europa, San Juan, Morir por cerrar los ojos (To Die by Closing One's Eyes), Tránsito (Transit), all are theatre pieces that tell us of the tragedy of having to flee one's own country and of the moral and existential dilemmas involved in exile. His great cycle, El laberinto mágico (The Magical Labyrinth), a Balzacian human comedy, but indeed more tragedy than comedy, six volumes intertwining stories of the civil war, is then concluded by Campo de los almendros (Field of the Almond Trees). I must confess that I could hardly read this novel to the end. I find it too painful to be read through. It is a novel taking place in the last residual place where Spanish Republicans gather after losing the war. This is Alicante, the last Republican stronghold, a port in the Levante, where thousands of people wait to be rescued by friendly ships. But only few of them will find a place on a boat. The rest are abandoned, left out, a flock of betrayed sheep. And once the Fascists arrive, actually first the Italian army, they are deported to the outskirts of that Spanish town, into a place that is called 
Campo de los almendros. There they are waiting to be selected and picked up, and either be immediately executed or sent to concentration camps. It is a sort of an open-air waiting hall, sala de espera; it is already exile, but in its worst shape, because it is an exile without escape. You are taken away from your country and home, but this does not secure you to stay alive. Sala de espera is also, and suggestively, the title of a journal edited by Max Aub in Mexico in the 1940s. To be sure, Joseph Roth too used the waiting room as an image to give a sense of his life after the loss of Felix Austria. He then used it to conceptualize the line between those who hold power and those who are subject to power, especially under conditions of mass migration. There are people that are left being waiting and people that are in charge to let others waiting, and this is an additional hierarchical division imposed to society. Again in Roth's words: 'Ich habe mich gewöhnt, die Menschen in zwei grosse Gruppen einzuteilen: in jene, denen das Vorzimmer ein Stück Leben bedeutet, und in solche, die keine Beziehung zum Vorzimmer gefunden haben, in solche, die warten, und in andere, die warten lassen.'

Lion Feuchtwanger's three thick volumes on the Weimar disaster and the destiny of German Democrats and Jews is given the name of Wartesaal Trilogie. Sala de espera, without hope, but with despair, this is exile. And many do not bear it. Campo de los almendros is a place where people massively suicided. And - we might remember - Ernst Tolle, another German refugee, committed suicide in New York, Stefan Zweig in Brazil, and Klaus Mann took his own life in the French Riviera.

It is thirty years later, in September 1969, when Max Aub comes back for a short visit to his hometown Valencia. One morning he timidly approaches the house where he was living in the 1930s. It is a bourgeois gorgeous white building, in French style, in Calle Almirante Cadarso 13. His family was the first to live there. He enters into the hall of the great building. It's dark, but an old lady is there in the concierge's, the head porter's small room, just at the entrance. She looks at him. He asks: 'Don't you know who I am?' At first she does not understand. And then she says aloud: 'Don Max!' She has suddenly recognized him. It is the same head porter of thirty years before, Clotilde. She is about to cry. 'Bajo a la calle a ver, a cien metros de este portal, el que fue el nuestro: Almirante Cadarso, 13. Está, naturalmente, igual; la casa la estrenamos nosotros (...) Al lado, en el solar, han construido una casa. Entro en la que fue nuestra. Hablo con la portera. Es Clotilde. La miro. No me conoce? Poco a poco le va cambiando la cara. Esta a punto de llorar. Don Max!' (La gallina ciega, The Blind Hen). It's like Ulysses recognized by his old nurse.

All this is told in the book that is the result of this first coming back, La gallina ciega, actually a diary of his visit, where the sentiment of exile is distilled in every word. He knows and feels the irremediable loss, and the impossibility of reconciliation. Spain hurts him. This is what makes exile. To render home a place where it hurts deeply. 'Wo es mir schlecht geht, dort ist mein Vaterland' - these are words by Joseph Roth. 'Where I feel bad, there is my fatherland.' This is what exile pro- 
duces: citizenship as an impossible experience of suffering and concern. I suffer, because I am concerned. And if I am concerned, this is my fatherland. ${ }^{5}$

But the suffering of exile, which is a radical form of concern, might sometimes express the real participation that makes one a citizen. So that we, the exiled, are converted into the real Spaniards, and the ones quietly sleeping in their beds in the Iberian Peninsula are stripped off their assumed and pretentious nationality. ‘Extranjeros, vosotros que dormis en vuestras camas! ¡Españoles nosotros, polvo y tierra de España, extranjeros en las arenas del Sahara!'

María Zambrano is not a novelist, though she has a special relationship to literature and poetry. As a matter of fact she believes that poetry somehow is a privileged form of philosophical thinking. And her philosophical prose is of a beautiful literary quality. Zambrano's use of the Spanish language and Max Aub's, are not too far away the one from the other. There is a Republican tinge in both of them, a rest of the language spoken in the 1930s, a poetical clang that is common.

María Zambrano is a philosopher, and she is the author of a work that makes her a relative - so to say - of a select group of thinkers that are all women and that are all refugees. This group consists of three main figures, Simone Weil, Hannah Arendt, and Rachel Bespaloff. These all are Jews, Zambrano is not. But they have much in common as is immediately evident to the eye.

They all are well-educated through the study of Classics, Greek and Latin culture; they all are being trained in philosophy, and adhere a philosophy with a clear existential tone. Arendt is a pupil of Heidegger, Weil and Bespaloff are students of Alain, Zambrano is a disciple of Ortega y Gasset. And all of them are exiles, refugees. Their sensibility is similar, they speak a same language, whereby philosophy is not external to human feelings and suffering. They ask for sense more than for truth, or better they believe that sense precedes truth. They do not equate knowing with thinking. And all of them interrogate themselves about belonging, loyalty, and home.

María Zambrano is disappointed by Ortega y Gasset's silence during the civil war in the same way as Hannah Arendt is disconcerted by Heidegger's silence about the Holocaust. Zambrano's way out from despair, appealing to a religious dimension seems sometimes close to Simone Weil's late mysticism. And Zambrano's attention to the Greek origins of European predicament is the same - we could say - as the one we find in Rachel Bespaloff's considerations about Homer's epic. ${ }^{6}$ As a matter of fact María Zambrano is closer to Hannah Arendt than to the late

5 Robert Neumann, another Austrian refugee, stretched that statement to the absurd: where you are bombed, there is your fatherland, ubi bombe, ibi patria (see Hilde Spiel, Rückkehr nach Wien. Ein Tagebuch (Berlin: Ullstein, 1989), 19.

6 See Rachel Bespaloff, De l'Iliade (Paris: Editions Allia, 2004). 
Simone Weil or Rachel Bespaloff. She is more an Aristotelian than a Platonic thinker. There is an amor mundi in her work, a strive for sharing her experience with fellow human beings, that we miss in the final phase of Simone Weil's writings and in Bespaloff's desperation.

There is a booklet by María Zambrano devoted to Seneca, published in 1944 in Argentina. In this work she is quite critical towards the great Roman philosopher. Seneca was living with too vivid a sense of the impending death to exit from himself. Seneca's extreme reflexivity never takes the form of asking for reasons, a claim for justification, and thus a movement of revolt. Nothing is more distinct from the Roman philosopher's calm attitude than the conduct of an angry Job challenging God's providence. 'Nada mas antisenequista que la queja de Job, al pedir cuentas a la divinidad.' Reason is by Seneca rigidly interpreted as moderation, arbitration, or kind of diplomacy between extremes; freedom is somehow annulled as an issue of etiquette and style. Resignation is his last word.

There is no claim to progress in Seneca's mode of action. He retreats from history and tragedy into philosophy. However, remarked María Zambrano in 1938, tragedy implies or needs some company, one is a son or a father, sister or brother, while philosophy will be mostly practiced in a lonely room: 'En la tragedia no se esta solo como en la filosofía; se es padre y se es hijo, se es también hermano y nada de esto admite abandono.' Acting was a matter of despair in Seneca's case, a way of forgetting, of making himself deaf to the bells of time devouring life. But time, for Zambrano as for Arendt, is not only the one that consumes life but also the one giving birth to it. It is nativity, the possibility of the radical novel, of something new, of change. From the past to the future the bridge is not given by strict causality. Although we are always in transit from the past towards the future, both individually and collectively, this can happen in various ways: 'Aunque en todo momento en la historia - tanto personal como colectiva - estemos viniendo del pasado y yendo hacia el futuro, puede esto suceder de diversa manera.'

History according to Zambrano is not cyclic; time has lapses, and gaps that can be filled through leaps, revolutions. There is thus room for hope; there can be a claim to progress. There should be, if we want to articulate and operationalize a claim to justice. And this involves other people. It needs citizenship. Both Zambrano and Arendt stress this point, though Arendt is quite pessimistic about a human condition stripped of the state, of the city. A man with only human rights is a being in great danger - says Arendt. Zambrano is less critical of this naked human being that she sees as the preparation and the justification of the citizen figure. Action for Zambrano, and this is a difference with Arendt of no little account, is not done for action's sake. A city is a required condition to give human condition a visible, public space: 'La ciudad, primera forma de vidad democratica, es el medio de visibilidad del hombre, donde aparece en su condicion de ser humano.'

The city of man however - according to Zambrano - finds its ultimate sense and justification in an ideal civitas dei, an individual, utopian area of practiced justice. 
While citizenship is the link we maintain with an earthly city of man, in civitas dei we can land only counterfactually, by thinking and confessing. Self-reflexivity is the road to the dimension of justice, the idealism of a possible better world for all humans. Practicing citizenship implies to be dwelling in two different worlds, a factual, and a counterfactual one, one belonging to man, the other to God.

Now, says María Zambrano, Europe's crisis is not due to the revolt of the masses, but to the loss of the individual revolting against injustice. Europe's promise was a way to reach utopia. If this way is barred, Europeans will lose their soul. They will prefer giving up liberty. 'Y por eso la más grave enfermedad europea sera la caricatura de su intima esperanza, la que envuelve la traición a su utopismo revolucionario de resurrección. Enfermedad que bajo la aparente energía oculta la desgana, la fatiga de seguir viviendo en tensión, en la tensión idealista del habitante de dos mundos.' Such illness consists fundamentally in a desire of cancelling the tension between facts and norms, better in an intoxication, a drunkenness, that makes us forget the unbridgeable distance between the two cities, the ideal and perfect one and the secular, permanently incomplete home. It is like a 'embriaguez que haga olvidar la distancia insalvable entre la dos ciudades, la de Dios siempre en el horizonte, y la de la tierra, siempre en edificación, que anule también la diferencia entre los dos hombres, entre el hombre concreto y el siempre naciente "hombre nuevo".'

Forgetting about the distance between facticity and normativity leads to a pragmatic cult of success, of fait accompli, to discriminating humanity in winners and losers, and eventually to a celebration of the winner and a degradation of the loser. The pain of such idiosyncratic idealism is marked by the pragmatic necessity of immediately and successfully annulling any time horizon in order to have everything instrumentally at hand: 'La fatiga de este consubstancial idealismo' - so we read in La agonía de Europa - 'puede llamarse pragmáticamente necesidad de éxito inmediato de destruir el horizonte para que todo esté al alcance de la mano'. In one of the best analyses of Europe's moral and political suicide at the end of the 1930s, Carlo Levi will call this illness, or intoxication, 'paura della libertà,' fear of freedom. ${ }^{7}$

Let me now shortly articulate the two different views on citizenship and exile expressed by Max Aub and María Zambrano. They are indeed different, and somehow opposed. We can extract a citizenship view from Aub's writings on exile and especially, though idiosyncratically, I believe, from his plays, his writings on Spanish literature, and the travel diary La gallina ciega. Zambrano's notion is easier to be spotted; it is to be drawn from her explicit considerations about the condition of being an exiled person and the question of reflexivity. This - according to her - is never to be fully found in a quietist position; I can give reasons to 
myself, only if I ask for them, and this is an exercise that implies a movement beyond what is status quo.

According to Max Aub citizenship is the capacity of being involved in a collective narrative that has a history and to which you can add a further episode. This is the reason why he is obsessed with his marginal condition with regard to the development of contemporary Spanish literature. Belonging and citizenship are a matter of sharing a story, and thus building a collective identity. It is taking part in a chain novel enterprise. If, however, you are not able to add a new chapter, be it by deeds or by action, then you have been relegated to an exile dimension. And you may start fantasizing about impossible deeds that never did take place, which is the gist of one of the most successful short stories written by Aub, La verdadera historia de la muerte de Francisco Franco (The True Story of the Death of Francisco Franco). You are a citizen if you do not feel comfortable in such capacity; a city, a home, is where you have worries and concerns, since you have vivid memory of what went and is going wrong.

A paradise is just the opposite of a city, since it would be a world without memory, 'un mundo donde no existiera la memoria.' Memory here offers a background of shared concern, and thus dignity, and a reference for judgment and possible reform. Where memory and shared dignity are cancelled the public sphere shrinks dramatically. This is why for Aub a paradigmatic case of city decadence is Vienna 1938 after the Anschluss, the forced annexation of Austria by the German Reich. ${ }^{8}$ Here there is no space left for citizens, no chance for civic action. The same sadly applies to Spain ruled by Franco. I cannot get back to Spain, he says to himself while visiting his beloved country after thirty years of exile, for here I cannot do anything, 'porque no puedo hacer nada' (La gallina ciega, p. 238).

According to María Zambrano citizenship is a quite different experience from the one we can derive through Max Aub's considerations. It is rather a default position where you can go back to, once you have been examining yourself in a solitary mood. Exile is a privileged place to discover a fatherland: 'el exilio es el lugar privilegiado para que la Patria se descubra'. A radical reflexivity of this kind might be however a disgrace, but only if you do not have any longer, if you have lost forever, that default place to refer back to.

Max Aub has of citizenship rather an interactive, not an introverted conception. Citizenship is a matter of your relationship to other fellow people. And it necessarily has an institutional dimension. A people only exists if it is able to choose, to vote: 'El pueblo existe si vota.' Citizenship is immediately made giving access to political rights.

Zambrano instead has a mono-logical, somewhat introverted idea of citizenship. This is conceived as the bedrock that makes the exercise of radical self-reflexivity possible, avoiding its slipping towards self-destruction. According to Zambrano 
you examine yourself, you reflect on your life, in an act of confessing. Self-reflexivity here means confession to yourself and to the entity that is overlooking your life, God, that gives you a reason. In this sense María Zambrano operates the passage from the thought of myself, the care of myself by myself, of the Stoic, to the care of myself by God's appeal, by confession to Him, that is done and recommended by Saint Augustin, actually one of the authors that the Spanish philosopher most assiduously read. Confessing needs articulating words, speaking up.

Silence is meaningless, when it is not a sin; it should be broken through confession. This is why Ortega y Gasset's silence about the Spanish civil war is so deeply disturbing, because it contradicts the requirements of self-reflexivity which is the one privilege of philosophy. Max Aub, who did not like Ortega, made fun of him, labelling him as too ready to confuse the world with his narrow milieu, 'muy dispuesto a confundir el mundo con su mundillo,' and in this way merging the spirit of time with his kitchen's smell, 'confundiendo el olor de la cocina con el del tiempo.' It was as if Ortega were not able to see what was going on in Spain after July 18th, 1936, unable to have an opinion about the Spanish civil war, as if he stopped thinking at all. This is especially appalling, if one agrees with Zambrano's claim that philosophy refers to poetry as its special form of expression. Poetry can never be done and received in the shape of silence. It is a music, but with propositional content; it needs words, a voice, as it is the case of confession and reflexivity by which one cannot remain mute, but has first to convey a meaning to oneself.

Citizenship in this perspective is a language by which those confessing words could be said and understood. It is also a space, a precinct, a house, where those words could be freely expressed and have a secured echo. Words without echo would be soon recaptured by silence and confession and reflexivity would become something void, empty. This the reason why they need citizenship as the capacity of giving one's words a special and certain echo. But on this conclusion Max Aub could not but agree. Echo - he would only add - implies to have a story to share and to be told together. If you might be an exile alone, lost to the others, and exile actually makes you prone and a prey to loneliness, you cannot be a citizen in a solitary mood, without others to embrace you as their fellow countrymen.

Max Aub's most famous and intense piece of theatre is San Juan, published in 1943, shortly after his arrival to Mexico. In it Aub summarizes his experience of exile and wanderer through France and Northern Africa. The story is that of a boat of Jews fleeing Nazi persecution and trying to find a country where to get refuge, seeking for asylum and a safe place. But this secure haven is cruelly refused to them. They are not allowed to land in any port. No country accepts them as refugees, no state wants them. So, the boat has to go back into high sea and recommence the quest for a safe haven.

The people on the boat are no longer citizens, but not yet refugees. Asylum is denied to them. They are worse than refugees, they find themselves plunged into a much more primordial condition, the one that tries to get the status of a refu- 
gee. The denial of such status makes them even less than naked human beings; they are dis-humanized, radically humiliated, pushed into a no man's land where no human rights hold, but just basic, primordial needs. This situation illustrates the connection between being a refugee and a citizen, and how much the one refers back to the other. But it also illustrates how much asylum is a basic legal condition for human beings that if denied makes of them something lower than men. This means that in a sense Hannah Arendt was wrong. Not only was she wrong of making not just legal subjectivity the right to have rights, but mainly of ascribing this generative capacity of rights only to citizenship. And she was wrong in not considering how much the status of a refugee might somehow be a safe place and a room for real basic rights.

Max Aub on the contrary does not complain of the refugee status as an antichamber to human nakedness, for he believes this stresses the need for guaranteeing a basic normative status, which, once granted, may later open the door to a fuller legal subjectivity, which is that of citizenship. It is the denial of the refugee status that is the real abyss of legal subjectivity, where one can only have the consolation of repeating the concluding phrase of San Juan: 'For he remembered that they were but flesh; a wind that passeth away, and cometh not again' ('Y acordose que eran carne; soplo que va y no viene') (Psalm 78:39).

María Zambrano's political theory is to be mainly found in two books, her very first one, Horizonte del liberalismo, published in 1930, where she elaborates on Ortega's liberalism and gives it a social-democratic twist, and a later one, Persona y democracia, written in Italian exile, in Rome, and published in 1958. The latest book is the one that best gives expression to Zambrano's mature thinking on polity and society. In this work we are proposed a general view of subjectivity that bases on two distinct modes of reflexivity, one private, that we could equate with the imputation of fundamental human rights, and another public, which is equivalent with citizenship. The former is the task of an individual, individuo, a sphere that necessarily separates subjects from society; the latter is the role of a person, persona, a subjectivity that is aware of itself and that goes beyond privacy and separation. Being a person, that is a public subject, refers to citizenship; while a stateless, a refugee, is no more than an individual, a being forced to privacy, a narrow sphere that can easily convert her, the stateless, the refugee, into a pariah. If one had to define democracy - she says -, this could be done by pointing out that democracy is a society where it is not only allowed, but also required to be a person: 'Si se hubiera de definir la democracia podria hacerse diciendo que es la sociedad en la cual no solo es permitido, sino exigido, el ser persona.'

In such conceptual constellation the main challenge for a democracy (where rule enforcement in principle should be universally compensated by rule deliberation) is that of granting individuals, stateless people, never to be degraded into pariahs, and of leaving open the chance for them to soon recover a citizen's status and dignity. But the other way round a democracy's fundamental task would be making citizens fully aware of their basic human condition, that is, that of a naked private subject and individual, and thus to signal that behind any persona there is always 
an individuo, an individual sometimes dramatically exemplified in the figure of the refugee and exile. Citizenship's fundamental justification is emancipating individuals from exile. This is its normative source.

A citizen's primordial condition is not that of belonging, but the one of being left alone and destitute, the one of a naked human being - this is Zambrano's claim. To get into a city, one had previously to be wandering in the desert, and to be needing and striving for acknowledging and being acknowledged by her fellow travellers as one of them by building a common home. But, while Zambrano stresses the compatibility and indeed the possible existential interconnection between exile and citizenship, Aub seems to deny or simply skip it. He is sceptical, and somehow afraid too, about a possible basic human condition without citizenship.

However, both Aub and Zambrano share the traditional Aristotelian view that belonging is fully civic and can be claimed and be operationalized as the position of a civis, a citizen, only if it is declined in terms of capacities and political rights and not just as a matter of heteronomous imputation. In this sense 'citizenship' is nationality redeemed from its merely ascriptive origin. To be a citizen implies in this way the possibility to be somehow a social actor, a 'builder', thus a reformer too, of that very special home that is a city. But, if citizenship is the status of a possible reformer, if it is rooted in a reformist, or evolutionary political attitude, its boundaries are not given once for all. More than rooted in conventional principles or a given destiny, political membership is built upon social interaction. ${ }^{9}$ The 'people' that is citizenship's ontological reference remains somewhat indeterminately defined; it is 'incomplete', and therefore open to be challenged in its character and thus possibly to be enlarged any time. ${ }^{10}$

9 See Massimo La Torre, Cittadinanza e ordine politico. Diritti, crisi della sovranità e sfera pubblica: una prospettiva europea (Turin: Giappichelli, 2004).

10 On the idea of an 'incomplete people' as reference for citizenship, cf. Étienne Balibar, Citizenship (London: Polity, 2015). 